themselves. The ILEA document suggests that one member of the "core team" should be nominated as the "leader" responsible for co-ordinating his colleague's activities. This makes nonsense of the core team co-ordinator and is dangerous if the nonmedical "lead" member has a higher authority than the consultant child psychiatrist. The medical profession should not bow to this committee-style direction on clinical decisions.

\section{Court Report}

The Court Report on the future of child health services? fell into the final trap created by the multidisciplinary team concept. Court recommended that each health district should have a special multidisciplinary handicap team based on the district general hospital working from the child development centre. The clinical functions include investigating and assessing children with complex disorders and arranging and co-ordinating their treatment. The operational function includes monitoring the effectiveness of the district service for handicapped children and maintaining the quality of the district's institutions. As in child psychiatry, it is important that there is an identifiable person responsible for the handicapped child's care and that he should be the most highly trained member-namely, the consultant. The team concept does not achieve this, but even more alarming is the mixing of clinical and operational functions. So far as we know this is an entirely new departure from established medical management and it opens the door to administrative control of the individual patient.

After the public outcry about battered babies the Health Departments created a web of district and area multidisciplinary committees and case conferences. These have had the effect of removing the responsibility and therefore the blame from any one individual. Though the publicity has died down, there has been no firm evidence that this multidisciplinary system has been any more effective in coping with the problem. Indeed, our impression is that it has given rise to greater difficulties. Instead of the case conference teams consisting of differing "professionals" individual members have specific statutory responsibilities, which they should carry out despite what the majority of the team may think. Furthermore, there is the uneasy association between the clinician responsible to the individual child and the police who are responsible for enforcing the law. More depends on the personalities of those concerned than the formal system so clumsily designed to deal with these tragic problems.

We are in no doubt that the multidisciplinary system has eroded clinical care in geriatric medicine, in psychiatry, and, increasingly, in paediatrics. The acute specialties have always considered themselves immune to this damaging development. But increasing pressure is being put on the general practitioner and we forecast that before long social workers or health visitors may be suggested as "lead" members of the team and would sift patients before they are reviewed by the primary health care teams. A paediatrician at Northwick Park Hospital has promoted the policy that when more than one child on an acute paediatric ward has diarrhoea, a multidisciplinary conference, consisting of the paediatricians and representatives of the nursing and ancillary staff, the district community physician, the consultant bacteriologist, and the control of infection officer, should meet to consider the management. ${ }^{8}$ This implies that paediatricians can no longer be trusted with the clinical management of their children on the ward.

The Health Service cannot afford an extensive multidisciplinary framework. At peripheral hospitals clinical decisions have to be taken quickly and the judicious use of the telephone makes the expense of a case conference unnecessary. If the multidisciplinary bandwagon rolls on doctors will lose their clinical responsibility and independence and patients will find themselves queueingeven longer than now-for their treatment to be undertaken by committees.

\section{References}

${ }^{1}$ General Medical Council, Professional Conduct and Discipline, May 1977. ${ }^{2}$ Royal Commission on the National Health Service, Report, Cmnd 7615. London, HMSO, 1979.

${ }^{3}$ Committee on Local Authority and Allied Personal Social Services, Report, Cmnd 3703. London, HMSO, 1968.

${ }^{4}$ South-east Thames RHA, Report of Committee of Inquiry, St Augustine's Hospital, Chartham, Canterbury, February 1976.

${ }^{5}$ DHSS, Review of the Mental Health Act, 1959, Cmnd 7320. London, HMSO, 1978.

${ }^{6}$ Inner London Education Authority, Relationship and leadership in child guidance units, 1978.

7 Committee on Child Health Services, Fit for the Future, Cmnd 6684. London, HMSO, 1976.

8 Valman, B, Paediatric Therapeutics. Oxford, Blackwell, 1979.

(Accepted 30 October 1979)

\section{Mansfield, Notts}

NORMAN BURNS, MB, MRCGP, general practitioner and chairman of the Central Nottinghamshire Health Finance Action Group in the new district general hospital. So at the beginning of this year we formed the Central Nottinghamshire Health Finance Action Group after a meeting sponsored by the local community health council and another of the staff side of the joint staff consultative committee, which had sought to discuss the cuts with the AHA, had met with rebuffs from the administration.

Faced with such an uphill task the group, with the hard work and enthusiasm of all its members, has certainly made the public aware of the cuts' consequences. Last month, after several signature-collecting days for a petition, a local day of protest was held and the petition presented to the AHA.

\section{Well advertised, well organised}

The first public meeting of a group like this must be well advertised and well organised and in Central Nottinghamshire the CHC had been publicising the issues in the local newspapers for some time. The group's title is important and if possible 
the initials should make an easily recognisable acronymthough I must admit that ours in Nottingham does not spring readily to mind. If district or area administrators (or both) can be persuaded to attend the meeting they can put forward the cold facts that will throw the emotional side of the argument into sharp relief. To give the group widespread appeal all political parties should be represented. At the first meeting a chairman, secretary, and treasurer should be appointed and a method of circularising supporters with information worked out. The CHC's participation is essential, for although the group should act independently the CHC secretary is an ideal person to act as its secretary to co-ordinate information, equipment, and contacts.

To start with there were no funds. In our case the $\mathrm{CHC}$ helped to pay the cost of the first newsletter, for which I paid half of the printing costs. Now, after several months, the CNHFAG has a fund to cover all expenses, with the money collected from trade unions, including NUPE, COHSE, and the NUM.

Accurate information is essential, for a false prospectus is the quickest way for a pressure group to be discredited. There is no excuse for not giving the correct facts in the newsletters, since operational plans, discussion documents, etc, pour out from regional, area, and district authorities to $\mathrm{CHCs}$, JSCCs, district medical committees, and medical executive committees. A clear distinction should be made, however, between facts and any interpretation, opinions, or policies based on the facts, for these are the real battlefield between the pressure group and the authority. All the information available makes the production of a newsletter relatively straightforward, though the facts and the policies have to be put across in a simple, easily understood manner.

On the practical side a typewriter, preferably with a carbon film, provides a quick way of "setting copy" and the use of lettraset to break up the sections gives an attractive appearance. This copy can be photocopied or scanned in an electronic stencil scanner to produce a vinyl stencil capable of doing 20000 copies without too much wear. An alternative method is to persuade someone to lend an offset litho machine: office models are now available and the local trade union office may well have one-in our case NUPE helped out. Distribution of leaflets can be difficult but public houses, clubs, libraries, and waiting rooms are good distribution points and sympathetic newsagents may agree to dispatch pamphlets with the morning papers.

\section{Demonstrations}

Some, but not all, action groups will want to organise a demonstration to gain more public support. Here my advice is, firstly, go to the police with a definite plan and date giving the expected numbers and composition of the marchers as well as the purpose of the march. You will need a large area for assembly and speeches away from the main streets. There should be a finishing point that has been agreed with those to whom the demonstration is to be made and a definite time for the completion of the whole affair. Most trade unions have placards and loud-hailers, which they will lend for a cause they support. Banners are best made by the organisers and this can be done quickly by cutting stencils and using a paint roller to paint with. All stewards should be identified by a distinctive arm band distributed on the day so that they cannot be copied. Coaches should be arranged for members of the public wishing to attend the meeting and at the assembly point and destination there should be a fixed timetable of named speakers who have been briefed on the content of their speech. But please remember, the organiser is responsible for the conduct of the demonstrators.

\section{Parliamentary liaison}

What about parliamentary liaison ? If properly organised this can be a great boost. The general election was announced just after our group was formed but despite the group's efforts to raise Health Service financing as a local issue the problems were ignored by the major parties and severe restraints placed on the group by the election laws, which permit comments from all candidates or from none on such a topic. Even so, the $\mathrm{CHC}$ managed to get an adjournment debate ${ }^{1}$ on Central Nottinghamshire in the House of Commons and the Under Secretary of State for Health agreed to meet representatives from the district. I was invited to attend as the group's chairman. It obviously helps if local MPs are sympathetic to the cause and can be persuaded to attend meetings. Any group with participating doctors that is contemplating similar action should liaise with the BMA's Press Information Department. I found its staff immensely helpful: they have considerable expertise on parliamentary relations and can organise meetings with MPs and prompt appropriate parliamentary questions.

It only remains for me to wish intending action-group doctors good luck in their endeavours.

\section{Reference \\ ${ }^{1}$ Hansard, House of Commons, 18 June 1979, col 1075.}

(Accepted 6 November 1979)

\section{Junior Members Forum 1980}

"The doctor-patient relationship" is the topic for the first day of the 1980 Junior Members Forum. The speakers are Professor Ian McColl (Guy's Hospital Medical School); Mrs Jean Robinson (past chairman of the Patients' Association and a lay member of the GMC); Dr Arnold Mendoza (HM coroner); and $\mathrm{Mr}$ John Montgomerie (a lawyer). The second day will be devoted to medicopolitical matters. Chaired by $\mathrm{Mr}$ Patrick Coyle, a surgical registrar in Swansea, the forum is on 29 and 30 March at the Milton Keynes College of Education.

The forum is for junior members of the BMA-that is, under 40 and within 12 years of registration. Doctors in general practice who wish to attend should contact their divisional secretary, those in hospital practice their regional HJS committee secretary, and those in community medicine or any other branch BMA House.

\section{"The Occupational Physician"}

We reported on 27 October that the Occupational Health Committee had revised and updated its guidance for full-time occupational physicians and doctors engaged part time in occupational medicine ( $\mathrm{p}$ 1085). Now called The Occupational Physician the publication will not be available before January 1980. 